\title{
Thinking Big: A Commentary on the Research Agenda in Academic Librarianship
}

\section{Paul Metz}

Library-related research has not fully realized its potential, in part because of its narrow focus. A perspective that approaches the academic library from the patron's point of view may lead to better results. Fundamental questions with broad policy implications remain to be asked about our collections and their use, about costs, and about both the academic setting itself and the people who work within it.

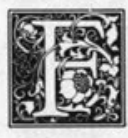

ew librarians dispute the potential benefits of library research. Research brings intelligence in both its meanings-as information about the environment, and as the application of wisdom and judgment to that information-to the task of libraries. One need not accept a faculty model for librarians in order to defend research: a look at the business world with its billion-dollar investments in product and market research should suffice.

Equally, few librarians will defend at length the actual benefits conferred by library research. Too often the same small issues have been reexamined in exacting methodological detail, imitating the social sciences at their worst. Alternatively, large issues are addressed ex cathedra, with little empirical substantiation. The result of these failures is a bimodal literature characterized at one extreme by the well done and trivial and at the other by relevant work that is merely anecdotal or hortatory.

The purpose of this essay is to refocus attention on substantive issues that can fully engage our best research efforts. I hope to emphasize the very good re- search, which has avoided both extremes described above, and to draw attention to possibilities for similar research in the future. The five areas in which I will discuss research that "thinks big" have little in common, but it may be notable that most of them represent the kinds of questions that outsiders, especially faculty and university administrators, tend to ask about libraries. This suggests that the key may be to forget a little of what we know in such detail and to step back so as to see our institutions from the outside.

\section{LIBRARY COSTS}

The dominant image of the library to academic administrators is often that of a cost center, a large factor in university overhead that consumes 2 to 5 percent of institutional resources while providing little instruction and less research. It is only natural that librarians' efforts to justify their budgets may lead them to regard cost reduction as an imposed agenda. Research on library costs has therefore been left chiefly to outsiders such as economists or accountants. This work has been generally competent, but even the best has inspired complaints that the techniques of li- 
brary processing have been misunderstood. ${ }^{1}$

Research on all areas of costs is needed, from processing to reference assistance and document delivery. We need to know whether shared cataloging, participation in approval plans, and internal automation may be primarily justified on cost grounds, and, if not, what extra costs may be attributed to these activities. We need to know at what point large centralized libraries become so cumbersome that economies of scale give way to diseconomies of scale, if indeed there is a point at which this occurs. ${ }^{2}$ Above all, we need cost attribution through the entire mill of processing, with special attention to the implications of key decisions on later outcomes. When selectors treat processing costs as an externality, as they almost invariably do, they tend to procure more esoteric materials for which cataloging costs are far higher. We need to know the costs associated with this practice before we can evaluate it.

In some cases, it is not the financial consequences of cost-motivated behavior that we need to know, but the service implications. For example, even if we can determine the savings associated with minimal-level cataloging, we can hardly make intelligent decisions without knowing the value to patrons of the access points normally omitted in minimal records and the resultant (admittedly intangible) costs of such omissions.

\section{LIBRARY USE}

Twenty-four years after the classic study by Herman Fussler and Julian Simon, we still don't know enough about use, and what we do know still has had little effect on practice. ${ }^{3}$ Nearly everyone recognizes the $80 / 20$ rule, but few practitioners can identify the materials that make up the "twenty," either in their own libraries or more generally. One implication of my own research is that because they depend so heavily on the makeup of a campus community, use patterns across subjects may vary widely from one institution to another. This limits the generalizability of "bottom line" statements about use, suggesting that libraries that desire detailed and accurate data on collections use will have to do their own studies.

Even where we have relatively clear findings, our research is not as useful as it might be. There is considerable evidence that journal use is highly concentrated and that citation data have some value in deselection decisions. There is less evidence that this has affected practice. In part, this may have occurred because the research has been conducted largely by nonlibrarians. ${ }^{5}$

Traditional questions about use-what is used or not used according to subject, format, age, and language-have received useful answers. But we still know less than we should about how intensively patrons will use materials in alternate formats such as videotape. We also do not know how microformats affect the use of journals and other materials. The point has been made that special collections, especially those that contain no significant materials of more than local importance, have associated costs that exceed the benefits obtained, but we have no empirical basis on which to evaluate this argument. ${ }^{6}$

Likewise, the profession has been slow to investigate far more interesting and rewarding questions. For example, integrated systems with full information on the status and discipline of borrowers open up exciting possibilities for telling us who uses what. Although the answers have profound implications for the grouping of collections and services and for other policy outcomes, I know of only three research projects of this type. None has been able to exploit fully the potential of the MARC record. ${ }^{7}$ I have indicated elsewhere the research that remains to be done in this area. ${ }^{8}$

\section{LIBRARY COLLECTIONS}

We don't know very well what we have or how our collections relate to one another. Experienced librarians understand why outsiders are naive if they expect us to perform inventories, but it is only in the past few years that real progress has been made in describing our collections in more summary, and more useful, ways. The current activity in describing collections 
via the Research Libraries Group (RLG) Conspectus and via overlap analysis is encouraging, and one hopes that such progress will continue.

Yet, overlap analysis will be merely a fad of interest only to bibliometricians unless librarians understand the policy implications of such research. Hendrik Edelman shows an appreciation of these implications when he tells us that his faith in cooperative development is reduced by the realization that the large collections in any area do not begin to cover their fields comprehensively. Sarah Thomas demonstrates the potential of overlap analysis by using it to discover how many of the Center for Research Libraries' periodical titles are held by enough other libraries to call into question the center's role as a backup resource for those titles. ${ }^{10}$

Related to the issue of collection overlap is the necessity of describing the political economy of interlibrary loan, or the net direction and proportion of lending traffic. Planning for networks and other cooperative ventures requires an understanding of this traffic in the typical case and in special cases such as Illinois, where planned interlibrary loan programs have greatly altered the total volume, the proportions between net lenders and net borrowers, and the transaction costs. ${ }^{11}$ Since overlap studies have shown many unique holdings in small collections, the means may be found to reduce greatly the disparities between net lenders and net borrowers. ${ }^{12}$

\section{HIGHER EDUCATION}

Are academic libraries large public libraries that happen to be located on campuses? Too often the literature of academic librarianship treats them as such. While the literature on bibliographic instruction has necessarily been sensitive to the respective roles of teaching faculty and librarians in the educational process, this sense of context is absent from research in other areas.

We need to pay equal attention to how librarians and other actors interact in library funding. We also need a better description of the informal ties that exist between librarians and faculty below the administrative level. We need research on the composition and role of university library committees and of search committees for library directors. We need to track changes in reporting structures now that a number of directors no longer report to the academic side of administration but rather to "information czars." For public institutions, system-wide library advisory committees have become significant forces in the environment, but this role has been all but ignored. ${ }^{13}$

\section{LIBRARY USERS}

While we need to study higher education as an institutional and administrative setting for our work, we also need to learn more about the behavior of individuals as they pursue research and instruction. Many user studies have been conducted, and many are rich in their implications about what we do. The many studies on user frustration done in the 1970s are an example of one of the best themes of this research, in terms of both the quality of the work itself and the significance of the conclusions. ${ }^{14}$ But here too, our focus has been highly selective. We have studied only certain user behaviors, those that occur inside the library itself.

An obvious question - and a good example of one that is particularly obvious to outsiders-is how changes in academic research have affected needs for library resources. Charles Osburn's analysis of academic research-showing its increasing quantification in all fields, the drift in critical theory away from textual and historical problems toward sociological analysis, and an introspective critical theory that becomes an object of study in itselfshould not be the only study we have that ties such large issues to questions of collection development. ${ }^{15}$

Beyond Osburn's question of what it is that scholars care to know, we should be more curious about how scholars work in and out of the library. Stephen Sloan has carefully assembled scattered parts of our literature that suggest that scholars do not and will not rely heavily on the access tools we champion. Sloan argues instead that scholars' reliance on one another and on the self-indexing character of specialized literatures make them dubious about 
the potential of use instruction to convey a realistic notion of how libraries can best be used. ${ }^{16}$ His study is another example of work that should not hold the solitary place in our literature that it does.

Curiosity about how researchers work should not be limited to the possibilities of traditional library research. All around us, activity progresses toward the "scholar's workstation," which will furnish in one place some combination of the following capabilities: access to local and remote databases; electronic mail both on campus and, through such facilities as EDUNET, beyond the campus; text editing, including the editing of results downloaded from bibliographic databases; numerical processing capabilities through tie-ins to mainframe computers; personal scratch pads; electronic bulletin boards; and automated scheduling. Which of these capabilities will really be wanted when economic realities dictate that choices be made, and which data resources will be most needed? Of all the examples where technology may be transferred to libraries without due regard for what makes the library unique, this is perhaps the most urgent.

Not the least important thing we need to know about our users is how they think, especially with regard to the retrieval of information. The more closely the struc- ture of library thesauri can reflect the cognitive processes by which humans encode, organize, and store information and the symmetrical strategies they use in attempting to retrieve it, the better these thesauri will work. Here we should enlist the assistance of psycholinguists. Suzanne Najarian's 1981 review of research on how human memory depends on hierarchical principles of organization, and on the implications of this finding for controlled vocabularies, is the third example I wish to cite of an item in our literature that should not be an isolate. ${ }^{17}$

\section{CONCLUSION}

What do libraries have? Who uses them and how do they approach them? These large questions occur to faculty and administrators who are interested in libraries but are not obliged to consider library routines. Because they can break such global issues down into tractable research questions to which they can bring data, librarians can address such issues without excessive generality and platitude. By bringing what we know best to the concerns that occupy our clientele, we can move library research away from its extremes and can discover a middle ground of important questions that can challenge our best researchers.

\section{REFERENCES}

1. William J. Baumol and Matityahu Marcus, Economics of Academic Libraries (Washington, D.C.: American Council on Education, 1973); Paul B. Kantor, Final Report on the Relation between Consortia, Online Services, and the Cost of Processing Monographs at Eight University Libraries (Cleveland, Ohio: Tantalus Inc., 1984).

2. Michael D. Cooper, "Economics of Scale in Academic Libraries," Library Research 5:207-19 (Summer 1983).

3. Herman H. Fussler and Julian L. Simon, Patterns in the Use of Books in Large Research Libraries (Chicago: University of Chicago Library, 1961).

4. Paul Metz, The Landscape of Literatures: Use of Subject Collections in a University Library (ACRL Publications in Librarianship no. 43), (Chicago: American Library Assn., 1983).

5. Stephen J. Bensman, "Journal Collection Management as a Cumulative Advantage Process,'" College \& Research Libraries 46:13-29 (Jan. 1985); Robert N. Broadus, "A Proposed Method for Eliminating Titles from Periodical Subscription Lists," College \& Research Libraries 46:30-35 (Jan. 1985).

6. Hugh F. Cline and Loraine T. Sinnott, Building Library Collections: Policies and Practices in Academic Libraries (Lexington, Mass.: Lexington Bks., 1981), p.147-50.

7. William E. McGrath, Donald J. Simon, and Evelyn Bullard, "Ethnocentricity and CrossDisciplinary Circulation," College \& Research Libraries 40:511-18 (Nov. 1979); Stephen Bulick, Structure and Subject Interaction: Toward a Sociology of Knowledge in the Social Sciences (New York: Dekker, 1982); Metz, Landscape of Literatures. 
8. Metz, Landscape of Literatures, p.110-11.

9. Pauline Atherton Cochrane and others, "Research Library Collections in a Changing Universe: Four Points of View," College \& Research Libraries 45:219-20 (May 1984).

10. Sarah E. Thomas, "Collection Development at the Center for Research Libraries: Policy and Practice," College \& Research Libraries 46:230-35 (May 1985).

11. Illinois Libraries 57:364-444 (entire issue).

12. William Gray Potter, "Studies in Collection Overlap: A Literature Review," Library Research 4:3-21 (1982).

13. An exception is Isaac T. Littleton, "State Systems of Higher Education and Libraries," in Robert D. Stueart and Richard D. Johnson, eds., New Horizons for Academic Libraries (New York: K. G. Saur, 1979), p.102-15.

14. Paul B. Kantor, "Availability Analysis," Journal of the American Society for Information Science 27:311-19 (Sept. 1976); Daniel Gore, "Let Them Eat Cake While Reading Catalog Cards: An Essay on the Availability Problem," Library Journal 100:93-98 (Jan. 15, 1975).

15. Charles B. Osburn, Academic Research and Library Resources: Changing Patterns in America (New Directions in Librarianship no. 3), (Westport, Conn.: Greenwood, 1979).

16. Stephen K. Stoan, "Research and Library Skills: An Analysis and Interpretation," College \& Research Libraries 45:99-109 (Mar. 1984).

17. Suzanne E. Najarian, "Organizational Factors in Human Memory," Library Quarterly 51:269-91 (July 1981). 